\title{
Pembuatan User Interface dan Animating pada Media Pembelajaran Interaktif Idiom Bahasa Inggris
}

\author{
Faizah Dinar, Yoyok SW \\ Program Studi Teknik Multimedia dan Jaringan \\ Jurusan Teknik Informatika dan Komputer \\ Politeknik Negeri Jakarta \\ faizahdinar@gmail.com, yoyok.sw@tik.pnj.ac.id
}

Diterima: 5 Maret 2016. Disetujui: 20 April 2016. Dipublikasikan: Mei 2016

\begin{abstract}
Abstrak - Idiom merupakan susunan kata-kata yang mempunyai arti khusus yang tidak diterjemahkan secara aksara (literally). Idiom digunakan untuk memberikan ciri khas bagi suatu kalimat sehingga banyak masyarakat yang menggunakannya dalam percakapan sehari-hari. Akan tetapi, idiom tidak masuk ke dalam kurikulum pendidikan bahasa Inggris di Indonesia, sehingga sulit bagi masyarakat yang ingin mempelajarinya. Banyak buku yang menjelaskan tentang idiom, namun belajar dari buku teks kini dianggap kurang efektif seiring berkembangnya teknologi dan multimedia. Dengan menggabungkan fungsi buku dan teknologi, maka akan lebih baik jika media pembelajaran dibuat dengan lebih interaktif dan membuat penggunanya lebih cepat menangkap ilmu yang diberikan dengan cara yang menyenangkan. Dalam pembuatan media pembelajaran interaktif ini dibutuhkan seorang desainer user interface yang berperan sebagai orang yang mendesain tampilan media interaktif dan animator yang berperan sebagai orang yang menganimasikan objek dalam sebuah cerita di dalam media interaktif tersebut. Pembuatan user interface dan animasi akan lebih baik dengan memanfaatkan prinsip perancangan user interface dan 12 prinsip animasi. Tampilan user interface mendapatkan presentase sebesar $\mathbf{8 6 , 6 - 9 3 , 3 \%}$ dari koreponden yang menyatakan bahwa tampilan user interface menarik dan tidak membingungkan. Untuk animasi mendapatkan presentase sebesar $\mathbf{7 3 , 3 - 8 3 , 4 \%}$ yang membuktikan bahwa animasi sudah baik dan sesuai. Sedangkan untuk aplikasi media pembelajaran interaktif ini mendapatkan presentase sebesar 80$100 \%$.
\end{abstract}

Kata Kunci: animasi, idiom, media pembelajaran, multimedia interaktif, user interface

\section{PENDAHULUAN}

Bahasa Inggris merupakan bahasa internasional nomor satu di dunia. Dalam mempelajari tata bahasa Inggris, terdapat banyak bagian yang harus dikuasai, seperti tenses, passive voice, elliptic structure, conditional sentence, idiom, dan lain-lain. Menurut Lado dalam bukunya yang berjudul English Grammar Plus Idioms, Idiom adalah susunan kata - kata yang mempunyai arti khusus yang tidak diterjemahkan secara aksara (literally). Idiom digunakan untuk memberikan ciri khas bagi suatu kalimat atau bahasan, sehingga banyak masyarakat yang menggunakannya dalam percakapan sehari-hari dan menjadikan idiom penting untuk dipelajari. Tetapi, idiom tidak masuk ke dalam kurikulum pendidikan bahasa Inggris di Indonesia, sehingga sulit bagi masyarakat yang ingin mempelajarinya.

Banyak buku yang menjelaskan mengenai idiom secara detail, namun belajar dari buku teks hanya mengandalkan indera penglihatan. Menurut penelitian oleh British Audio-Visual Association, proses pembelajaran akan lebih menguntungkan jika mengandalkan indera penglihatan, pendengaran dan sentuhan. Dengan memanfaatkan teknologi multimedia, inovasi-inovasi media pembelajaran yang menggabungkan indera-indera tersebut bermunculan, salah satunya yaitu multimedia interaktif.

Menurut Hofstetter, multimedia interaktif adalah pemanfaatan komputer untuk membuat dan menggabungkan teks, grafik, audio, gambar bergerak (video dan animasi) dengan menggabungkan link dan tool yang memungkinkan user melakukan navigasi, berintraksi, berkreasi dan berkomunikasi [1]. Dengan menggabungkan fungsi buku dan teknologi, maka akan lebih baik jika media pembelajaran dibuat dengan lebih interaktif dan membuat penggunanya lebih cepat menangkap ilmu yang diberikan dengan cara yang menyenangkan.

"Media Pembelajaran Interaktif Idiom Bahasa Inggris" merupakan sebuah media pembelajaran yang mempelajari tentang penggunaan idiom dalam percakapan sehari-hari. Media pembelajaran ini terdiri dari beberapa cerita animasi 2 dimensi dengan karakter yang menggunakan idiom bahasa inggris dalam percakapan seharihari, penjelasan tentang idiom yang digunakan, latihan, serta game tentang idiom itu sendiri. 
Dalam pembuatan media pembelajaran interaktif ini dibutuhkan seorang desainer user interface untuk mendesain tampilan media interaktif dan animator untuk menganimasikan objek dalam sebuah cerita di dalam media interaktif tersebut. User interface merupakan bentuk tampilan grafis yang menghubungkan antara user dengan sistem sehingga memudahkan user dalam menjalankan suatu program dan eksekusi perintah yang ada pada sistem.[2] Animasi adalah proses penciptaan efek gerak yang terjadi selama beberapa waktu. Animasi juga merupakan suatu teknik menampilkan gambar berurut sedemikian rupa sehingga penonton merasakan adanya ilustrasi gerakan (motion) pada gambar yang ditampilkan [3]. Jadi, animating merupakan suatu proses penggerakan animasi.

Penelitian ini dapat menambah wawasan pada bidang desain dan animating sehingga dapat diterapkan dalam pembuatan media pembelajaran interaktif. Berdasarkan latar belakang yang telah diuraikan, muncul permasalahan sebagai berikut:

1) Bagaimana desain user interface pada media pembelajaran interaktif?

2) Bagaimana animating untuk cerita animasi 2 dimensi pada media pembelajaran interaktif?

Batasan masalah dalam Pembuatan User Interface dan Animating pada Media Pembelajaran Interaktif Idiom Bahasa Inggris" adalah:

1) Pembuatan konsep dan desain user interface pada media pembelajaran interaktif.

2) Pembuatan desain user interface menggunakan perangkat lunak Adobe Illustrator dan Adobe Photoshop.

3) Animating untuk cerita animasi 2 dimensi pada media pembelajaran interaktif.

4) Proses animating menggunakan perangkat lunak Adobe After Effect.

5) Media pembelajaran interaktif ini berisi 60 idiom bahasa Inggris.

6) Media pembelajaran interaktif ini ditujukan untuk user dengan range usia antara 12-24 tahun.

Tujuan "Pembuatan User Interface dan

Animating pada Media Pembelajaran Interaktif Idiom Bahasa Inggris" adalah:

1) Membuat desain user interface pada media pembelajaran interaktif.

2) Membuat animating untuk cerita animasi 2 dimensi pada media pembelajaran interaktif.

Manfaat dalam "Pembuatan User Interface dan Animating pada Media Pembelajaran Interaktif Idiom Bahasa Inggris" adalah:

1) Manfaat dari pembuatan desain user interface adalah untuk memberikan tampilan media pembelajaran yang mudah digunakan dan user friendly, sehingga tidak membuat user kesulitan saat menggunakan media pembelajaran ini.

2) Manfaat dari animating adalah untuk membuat suatu animasi dengan memberikan gerakan pada gambar (karakter dan background) agar gambar terlihat dinamis dalam membentuk suatu cerita. Sehingga animasi tersebut dapat membantu para user untuk memahami tentang isi dari media pembelajaran ini.

\section{TINJAUAN PUSTAKA}

\section{A. Media Pembelajaran}

Media bentuk jamak dari medium, yang berarti pengantar terjadinya komunikasi dari pengirim menuju penerima pesan. Media merupakan salah satu komponen komunikasi sebagai pembawa pesan dari komunikator menuju komunikan. Jadi, media pembelajaran adalah segala sesuatu yang dapat digunakan untuk menyalurkan pesan (bahan pembelajaran), sehingga dapat merangsang perhatian, minat, pikiran, dan perasaan siswa dalam kegiatan belajar untuk mencapai tujuan belajar [4].

Media pembelajaran meliputi alat yang secara fisik digunakan untuk menyampaikan isi materi pengajaran, yang terdiri dari antara lain buku, taperecorder, kaset, video camera, video recorder, film, slide (gambar bingkai), foto, gambar, grafik, televisi, dan komputer [5]. Kualitas proses pembelajaran sangat dipegaruhi oleh media pembelajaran yang digunakan. Media pembelajaran dibagi menjadi menjadi tiga kategori utama yaitu ; 1) media penyaji adalah media yang mampu menyajikan informasi; 2) media obyek adalah media yang mengandung informasi; 3) media interaktif adalah media yang memungkinkan untuk berinteraksi [6].

\section{B. Multimedia Interaktif}

Multimedia interaktif adalah pemanfaatan komputer untuk membuat dan menggabungkan teks, grafik, audio, gambar bergerak (video dan animasi) dengan menggabungkan link dan tool yang memungkinkan user melakukan navigasi, berinteraksi, berkreasi dan berkomunikasi [7] Multimedia interaktif sebagai bahan ajar bertujuan : 1) memperjelas dan mempermudah penyajian pesan agar tidak terlalu bersifat verbalistis. 2) mengatasi keterbatasan waktu, ruang, dan daya indra para siswa. 3) dapat digunakan secara tepat dan bervariasi, seperti : meningkatkan motivasi dan gairah belajar para siswa untuk menguasai pelajaran secara utuh, mengembangkan kemampuan siswa dalam berinteraksi langsung lingkungan dan sumber belajar lainnya terutama bahan ajar yang berbasis ICT, memungkinkan siswa untuk belajar secara mandiri sesuai kemampuan dan minatnya [8].

\section{Idiom}

Idiom adalah susunan kata-kata yang mempunyai arti khusus yang tidak diterjemahkan secara aksara (literally). Idiom dibuat dengan menetapkan arti baru untuk kata-kata yang telah 
memiliki maknanya atau disebut 'verbal' idiom. Misalnya, sudah menjadi hal yang biasa dalam bahasa Inggris ketika untuk mengungkapkan berbagai tindakan, diperlukan penambahan satu atau lebih makna pada kata kerja. Dengan demikian, 'to come', yang awalnya memiliki arti 'to arrive', nantinya digunakan dalam ekspresi rupa 'to came off', yang berarti bahwa beberapa peristiwa telah terjadi [9].

Idiom juga dapat digambarkan sebagai ungkapan yang maknanya berubah dengan mengubah arti dari kata-kata yang membentuk ekspresi, seperti, 'to think of it', yang berarti mengingat sesuatu yang terjadi di masa lalu, atau idiom 'in the lap of luxury' digunakan untuk menggambarkan gaya hidup orang kaya. Selain itu, ada kelompok idiom berkedudukan kuat yang besar jumlahnya, seperti 'a hard nut to crack', yang digunakan untuk menggambarkan masalah yang sulit, atau 'to keep one's nose clean', untuk memperingatkan seseorang untuk memimpin kehidupan yang benar dan tidak terlibat dalam tindakan-tindakan ilegal [9].

\section{User Interface}

User interface atau antarmuka pengguna adalah bentuk tampilan grafis yang menghubungkan antara user dengan sistem sehingga memudahkan user dalam menjalankan suatu program dan eksekusi perintah - perintah yang ada pada sistem.[2] User Interface merupakan bagian dari komputer dan perangkat lunaknya yang dapat dilihat, didengar, disentuh, dan diajak bicara, baik secara langsung maupun dengan proses pemahaman tertentu [10].

Prinsip-prinsip dalam merancang user interface adalah sebagai berikut [11]:

- User familiarity/mudah dikenali: gunakan istilah, konsep dan kebiasaan user bukan komputer (misal: sistem perkantoran gunakan istilah letters, documents, folders bukan directories, file, identifiers

- Consistency/“selalu begitu”. konsisten dalam operasi dan istilah di seluruh sistem sehingga tidak membingungkan.

- Minimal surprise/tidak membuat kaget user: operasi bisa diduga prosesnya berdasarkan perintah yang disediakan.

- Recoverability/pemulihan: ada dua macam, yaitu confirmation of destructive action (konfirmasi terhadap aksi yang merusak) dan ketersediaan fasilitas pembatalan (undo).

- User guidance/bantuan: sistem manual online, menu help, caption pada icon khusus tersedia.

- User diversity/keberagaman: fasilitas interaksi untuk tipe user yang berbeda disediakan, misalnya ukuran huruf bisa diperbesar.

\section{E. Animasi}

Definisi animasi berasal dari kata 'to animate' yang berarti menggerakkan, menghidupkan. Animasi adalah proses penciptaan efek gerak atau efek perubahan bentuk yang terjadi selama beberapa waktu. Animasi juga merupakan suatu teknik menampilkan gambar berurut sedemikian rupa sehingga penonton merasakan adanya ilustrasi gerakan (motion) pada gambar yang ditampilkan. Definisi tersebut mengartikan bahwa benda-benda mati dapat 'dihidupkan'. Pengertian tersebut hanyalah merupakan istilah yang memiripkan, dalam arti tidak harus diterjemahkan secara denotatif, melainkan simbol yang menyatakan unsur kedekatan [3].

1) Jenis Animasi

Secara umum teknis pembuatan animasi dibagi menjadi tiga jenis, yaitu: animasi 2D, animasi 3D, dan stop motion [12]

2) Prinsip - Prinsip Animasi

Prinsip-prinsip animasi digunakan para animator sebagai pedoman utama gambar bergerak menjadi lebih hidup sehingga seorang animator dapat mengetahui dan memahami bagaimana sebuah animasi dibuat sedemikian rupa agar didapatkan hasil animasi yang menarik, dinamis dan tidak membosankan. [13]

Dua orang animator profesional Thomas dan Ollie Johnston memberikan 12 prinsip animasi yang di adopsi dari animasi produksi Walt Disney [13], yaitu:

1. Squash and Stretch

2. Anticipation

3. Staging

4. Straight Ahead and Pose to Pose

5. Follow Through and Overlapping Action

6. Slow In and Slow Out

7. Archs

8. Secondary Action

9. Timing

10. Appeal

11. Exaggeration

12. Solid Drawing

\section{F. Adobe Photoshop}

Adobe Photoshop adalah perangkat lunak editor citra buatan Adobe Systems yang dikhususkan untuk pengeditan foto maupun gambar dan pembuatan efek. Perangkat lunak ini banyak digunakan oleh fotografer digital dan perusahaan iklan sehingga dianggap sebagai pemimpin pasar untuk perangkat lunak pengolah gambar atau foto [14].

\section{G. Adobe Illustrator}

Adobe Illustrator adalah perangkat lunak yang dibuat oleh Adobe System. Adobe Illustrator dapat membuat segala sesuatu dari grafis sederhana, ikon, 
dan teks hingga ilustrasi kompleks dan multilayered, yang semuanya dapat digunakan dengan page layout dalam presentasi multimedia atau web [15].

\section{H. Adobe After Effect}

Adobe After Effects merupakan salah satu perangkat lunak yang dikembangkan oleh Adobe System. Adobe After Effect adalah sebuah perangkat lunak editing video kelas dunia yang banyak digunakan dalam dunia perfilman untuk mengedit video seperti menambah efek suara, efek animasi, bahkan efek 3D. Perangkat lunak ini sangat berguna untuk membuat dan mengembangkan gambar yang dinamis, membuat animasi, melakukan editing video, serta menambah efek-efek spektakuler.

\section{Duik Tools}

Duik (Ringging Duduf IK Animation) adalah sebuah tools animasi yang komprehensif dan script untuk membuat rigging di Adobe After Effect [16]. Rigging adalah pemberian tulang (bone) pada objek yang akan dibuat animasi. Duik menyediakan tools utama rigging, yang biasa ditemukan di perangkat lunak 3D seperti IK, controller, dan bones dengan menyesuaikannya untuk animasi 2D di After Effect. Dengan menggunakan Duik, user dapat membuat rig karakter kompleks dan menggunakan teknik animasi canggih yang biasanya digunakan di perangkat lunak 3D.[16]

\section{J. Adobe Premiere Pro}

Adobe Premiere Pro merupakan perangkat lunak video editing yang sangat populer di kalangan profesional maupun user awam yang menyukai video editing. Perangkat lunak ini memiliki tampilan yang mudah digunakan dan didesain oleh Adobe System [17].

\section{K. Penelitian Terdahulu}

Penelitian yang berjudul Pengembangan Multimedia Pembelajaran Interaktif Untuk Mata Kuliah Organisasi Komputer yang ditulis oleh Wawan Saputra dan Bambang Eka Purnama berisi tentang pembuatan $\mathrm{CD}$ interaktif dengan menggunakan Adobe Flash CS3. Dalam media pembelajaran ini, tidak menggunakan animasi pada penjelasan materinya. Pembuatan user interfacenya tidak menggunakan perangkat lunak lain akan tetapi menggunakan perangkat lunak yang sama dengan perangkat lunak utama yaitu Adobe Flash CS3. Desain user interface yang dihasilkan terlihat formal dan kaku serta pewarnaanya terlihat kelam karena menggunakan background berwarna gelap sehingga terlihat user interface dari media pembelajaran ini menjadi kurang menarik.[18]

Dari hasil penelitian yang dilakukan oleh Ridho Wijayanto menghasilkan "Perancangan Animasi Interaktif Pembelajaran Bahasa Inggris
Untuk Kelas 2 Pada MI Nurul Falah Ciater". Animasi pada media pembelajaran ini dibuat dengan pergerakan sederhana dan menggunakan perangkat lunak Adobe Flash Professional CS 5.5. Selain itu, desain user interface dari media pembelajaran ini terlihat kurang menarik karena kurang serasi antara font, warna, tombol dan background [19].

\section{Buku Idiom}

Buku Idiom yang digunakan sebagai referensi yaitu berjudul Resitasi Idiom Itu Menyenangkan karya B. Puramdara Aswin. Buku ini diperuntukkan bagi pelajar bahasa Inggris, terutama bagi para pemula, agar mereka tidak ragu lagi dalam menguasai idiom. Hal ini disebabkan karena idiom memiliki arti dan makna yang berbeda bila diterjemahkan secara langsung. Dalam buku ini terdapat kumpulan idiom dalam peristiwa kehidupan sehari-hari, contoh penggunaan idiom dalam kalimat dan kamus idiom [20].

\section{PERANCANGANDAN REALISASI}

A. Perancangan Media Pembelajaran Interaktif Dalam pembuatan media pembelajaran interaktif dibutuhkan perencanaan yang matang agar menghasilkan media pembelajaran yang baik. Perancangan media pembelajaran interaktif yang penulis buat dikhususkan pada perancangan dan pembuatan user interface dan animating yang digunakan di dalam media pembelajaran interaktif. Metode dasar yang menjadi acuan penulis menggunakan metode Luther (1994), dimana metode ini meliputi tahap-tahap sebagai berikut:

1) Concept, yaitu menentukan tujuan dan siapa pengguna program (identification audience), tujuan aplikasi (informasi, hiburan, pelatihan, dan lain-lain, dan spesifikasi umum.

Pada tahap ini spesifikasi yang ditentukan yaitu pembuatan desain user interface yang mudah digunakan (user friendly) dan indah dipandang mata (eye-catching) serta animasi yang sesuai dengan storyboard.

2) Design, yaitu tahap dalam membuat spesifikasi secara rinci mengenai arsitektur program, gaya, tampilan dan kebutuhan material untuk program. Pada tahap ini dilakukan pembuatan konsep desain user interface dan storyboard untuk animasi.

3) Material Collecting, tahap pengumpulan bahan yang sesuai dengan kebutuhan yang dikerjakan. Bahan-bahan tersebut, antara lain gambar icon, foto, animasi, video, audio.

Pada tahap ini dilakukan pengumpulan asset untuk desain user interface dan animasi, baik yang dilakukan sendiri oleh penulis maupun yang telah dibuat oleh anggota tim lain. 
4) Assembly, tahap pembuatan semua objek atau bahan multimedia. Pada tahap ini dilakukan pendigitalisasian dari konsep desain user interface dan animating cerita sesuai dengan storyboard.

5) Testing, yaitu tahap testing (pengujian) dilakukan setelah menyelesaikan tahap assembly. Pada tahap ini dilakukan pengujian pada desain user interface, apakah sudah sesuai dengan spesifikasi yang telah ditentukan. Serta pengujian terhadap animasi yang telah dibuat, apakan telah sesuai dengan storyboard dan dapat dipahami cerita dari animasi tersebut.

6) Distribution, yaitu tahap akhir pengemasan dan penyebaran dari produk. Pada tahap ini, dilakukan proses pengemasan dan penyebaran aplikasi komputer media pembelajaran interaktif idiom bahasa Inggris dalam percakapan seharihari yang sudah diselesaikan yang mana bentuk distribusinya berupa CD.

\section{B. Deskripsi Perancangan Media Pembelajaran Interaktif}

Berdasarkan metodologi Luther, langkah awal pembuatan media pembelajaran interaktif dimulai dengan pembuatan konsep, dimana konsep dari media pembelajaran interaktif "Speak Your Idiom" dijabarkan pada Tabel 1.

TABEL 1. KONSEP PRODUK MULTIMEDIA

\begin{tabular}{|c|c|c|}
\hline Jenis Produk & $:$ & Media Pembelajaran Interaktif \\
\hline Nama Produk & $:$ & Speak Your Idiom \\
\hline Tujuan Produk & : & $\begin{array}{l}\text { Membantu proses pembelajaran idiom } \\
\text { bahasa inggris dalam kehidupan sehari - } \\
\text { hari }\end{array}$ \\
\hline $\begin{array}{l}\text { Konten } \\
\text { Produk }\end{array}$ & & $\begin{array}{l}\text { Video cerita animasi } 2 \text { dimensi } \\
\text { sederhana, exercise, mini game, \& video } \\
\text { motion graphic }\end{array}$ \\
\hline $\begin{array}{l}\text { Target } \\
\text { Audiens }\end{array}$ & & Usia $12-24$ tahun \\
\hline Output & : & Aplikasi komputer (.exe) \\
\hline
\end{tabular}

Media pembelajaran interaktif "Speak Your Idiom" memiliki dua bagian utama. Bagian pertama adalah Story yang berisi teori idiom bahasa Inggris yang dikemas ke dalam cerita animasi sederhana berbentuk percakapan (conversation). Dalam media pembelajaran interaktif ini, terdapat 5 Story yang masing-masing berisi 12 idiom yang dapat dipelajari oleh user. Pada setiap akhir Story, user dapat mengevaluasi pemahaman mereka mengenai materi idiom yang telah dipelajari dengan mengisi latihan (exercise). Bagian kedua dari media pembelajaran interaktif ini adalah Game. Pada bagian Game, user dapat memainkan permainan yang masih berhubungan dengan materi pembelajaran yaitu idiom bahasa Inggris. Pada media ini terdapat 2 permainan yang menyenangkan dan menghibur sehingga user tidak jenuh untuk mempelajari materi yang disediakan. Media pembelajaran interaktif ini, menggunakan bahasa Inggris sebagai bahasa utamanya.

\section{Cara Kerja Media Pembelajaran Interaktif}

Cara kerja pada media pembelajaran interaktif ini masih menggunakan metodologi yang sama yaitu metode Luther. Pada Gambar 1 terdapat flowchart keseluruhan yang digunakan di dalam media pembelajaran interaktif "Speak Your Idiom".

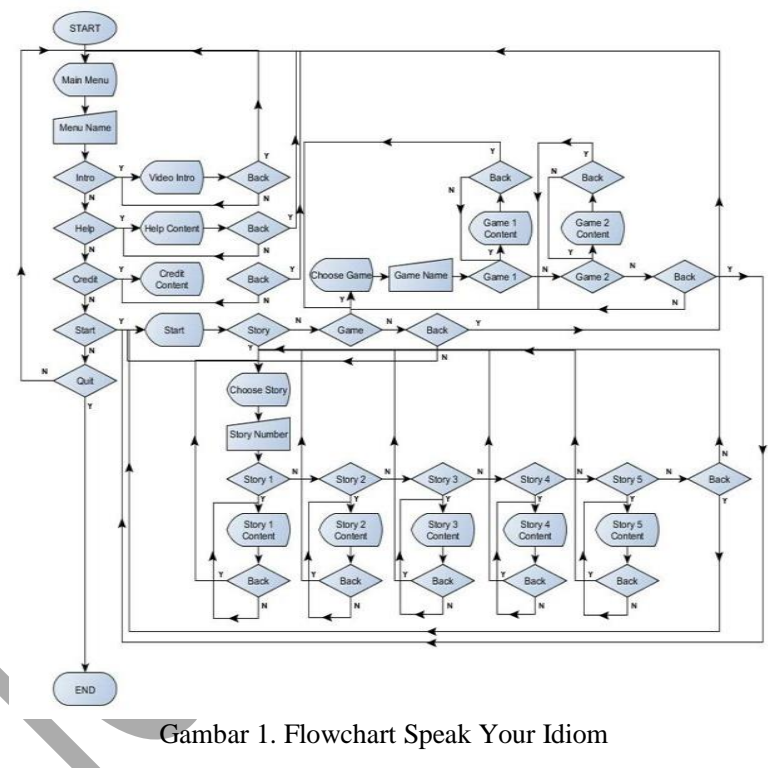

D. Rancangan Media Pembelajaran Interakif

Rancangan media pembelajaran interaktif termasuk ke dalam tahap desain pada metodologi Luther. Pada tahap ini, penulis membuat sketsa desain untuk user interface berdasarkan flowchart yang sebelumnya dibuat, skenario untuk animasi, dan storyboard untuk animasi.

\section{E. Sketsa User Interface/Antarmuka Pengguna}

Sketsa user interface dibuat untuk memudahkan dalam pembuatan desain user interface pada media pembelajaran interaktif yang sebenarnya. Tabel 2 merupakan sketsa desain user interface beserta penjelasannya.

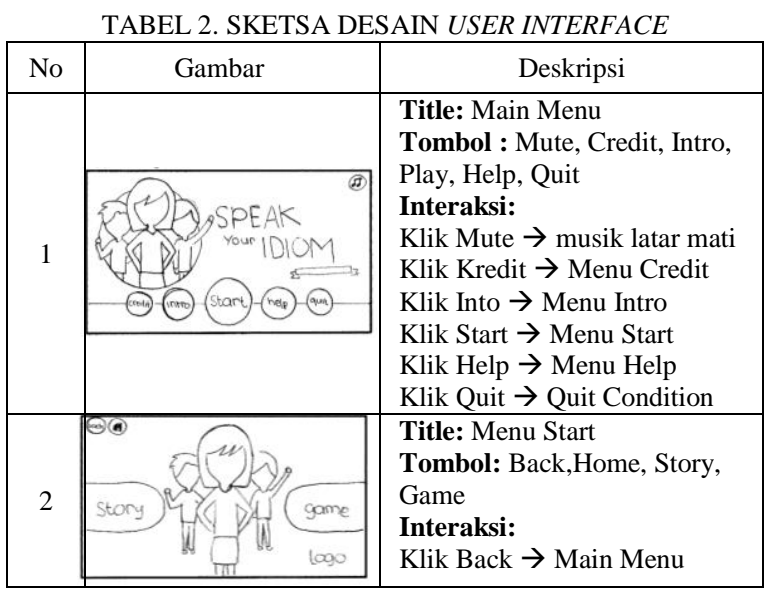




\begin{tabular}{|c|c|c|}
\hline & & $\begin{array}{l}\text { Klik Home } \rightarrow \text { Main Menu } \\
\text { Klik Story } \rightarrow \text { Menu Story } \\
\text { Klik Game } \rightarrow \text { Menu Game }\end{array}$ \\
\hline 3 & Coredit) & $\begin{array}{l}\text { Title: Menu Credit } \\
\text { Tombol : Back } \\
\text { Interaksi: } \\
\text { Klik Back } \rightarrow \text { Main Menu }\end{array}$ \\
\hline 4 & video & $\begin{array}{l}\text { Title: Menu Intro } \\
\text { Tombol : Back } \\
\text { Interaksi: } \\
\text { Klik Back } \rightarrow \text { Main Menu }\end{array}$ \\
\hline 5 & heip) bop & $\begin{array}{l}\text { Title: Menu Help } \\
\text { Tombol : Back } \\
\text { Interaksi: } \\
\text { Klik Back } \rightarrow \text { Main Menu }\end{array}$ \\
\hline 6 & & $\begin{array}{l}\text { Title: Menu Story } \\
\text { Tombol : Back, Home, Story } \\
\text { 1, Story 2, Story 3, Story 4, } \\
\text { Story } 5 \\
\text { Interaksi: } \\
\text { Klik Back } \rightarrow \text { Main Menu } \\
\text { Klik Story 1, 2, 3, 4, } 5 \rightarrow \text { Play } \\
\text { Story }\end{array}$ \\
\hline 7 & anim & $\begin{array}{l}\text { Title: Video Story } \\
\text { Tombol : Back, Next } \\
\text { Interaksi: } \\
\text { Klik Back } \rightarrow \text { Main Menu } \\
\text { Klik Next } \rightarrow \text { Theory } \\
\text { Description } \\
\end{array}$ \\
\hline 8 & & $\begin{array}{l}\text { Title: Theory Description } \\
\text { Tombol : Back, Home, Next } \\
\text { Interaksi: } \\
\text { Klik Back } \rightarrow \text { Video Story } \\
\text { Klik Home } \rightarrow \text { Main Menu } \\
\text { Klik Next } \rightarrow \text { Menu Exercise }\end{array}$ \\
\hline 9 & $\theta$ & $\begin{array}{l}\text { Title: Theory Explanation } \\
\text { Tombol : Back, Next } \\
\text { Interaksi: } \\
\text { Klik Back } \rightarrow \text { Menu Theory } \\
\text { Klik Next } \rightarrow \text { Menu Exercise }\end{array}$ \\
\hline 10 & & $\begin{array}{l}\text { Title: Exercise Description } \\
\text { Tombol: Back, Home, Next } \\
\text { Interaksi: } \\
\text { Klik Back } \rightarrow \text { Theory } \\
\text { Description } \\
\text { Klik Home } \rightarrow \text { Main Menu } \\
\text { Klik Next } \rightarrow \text { Menu Exercise }\end{array}$ \\
\hline 11 & 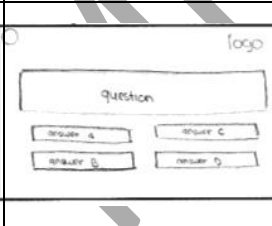 & $\begin{array}{l}\text { Title: Exercise Question } \\
\text { Tombol : Back, Opsi 1, Opsi } \\
\text { 2, Opsi 3, Opsi } 4 \\
\text { Interaksi: } \\
\text { Klik Back } \rightarrow \text { Theory } \\
\text { Explanation } \\
\text { Klik Opsi } 1-4 \rightarrow \text { Cek Jawaban }\end{array}$ \\
\hline 12 & $\begin{array}{l}\text { Congratulation } \\
\text { yas secenc is } \\
X \text { of } X \\
\text { anather thay }\end{array}$ & $\begin{array}{l}\text { Title: Exercise Result } \\
\text { Tombol : Another Story } \\
\text { Interaksi: } \\
\text { Klik Another Story } \rightarrow \text { Menu } \\
\text { Story }\end{array}$ \\
\hline 13 & D) & $\begin{array}{l}\text { Title: Menu Game } \\
\text { Tombol : Back, Home, } \\
\text { Detective Idioms, Idioms In } \\
\text { Melodies } \\
\text { Interaksi: } \\
\text { Klik Back } \rightarrow \text { Menu Start } \\
\text { Klik Detective Idioms } \rightarrow \\
\text { Game Detective Idioms } \\
\end{array}$ \\
\hline
\end{tabular}

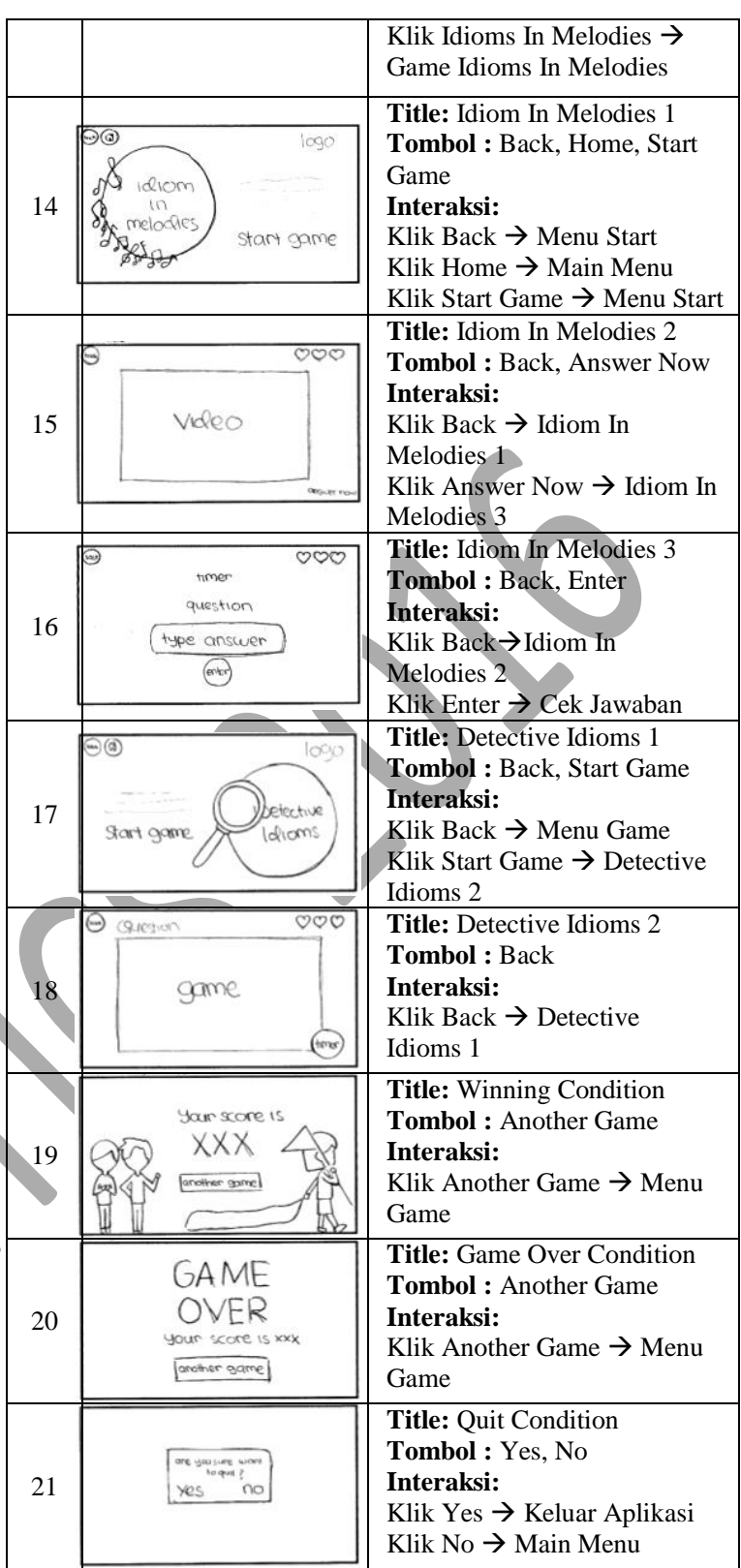

\section{F. Skenario Animasi}

Pada media pembelajaran interaktif "Speak Your Idiom" terdapat bagian Story yang berisi cerita animasi sederhana. Oleh karena itu, diperlukan skenario untuk membuat cerita tersebut.

\section{G. Storyboard Animasi}

Storyboard animasi dibuat untuk memudahkan proses animating pada bagian cerita. Gambar 2 merupakan storyboard dari beberapa scene dalam pembuatan animasi ini.

\section{H. Material Collecting}

Material collecting merupakan tahap yang dilakukan setelah tahap desain selesai pada metodologi Luther. Tahap ini merupakan tahapan pengumpulan aset yang digunakan pada pembuatan 
user interface dan animating dalam media pembelajaran interaktif "Speak Your Idiom". Asetaset tersebut berupa skenario, storyboard, sketsa, font, audio, file psd dan lainnya.

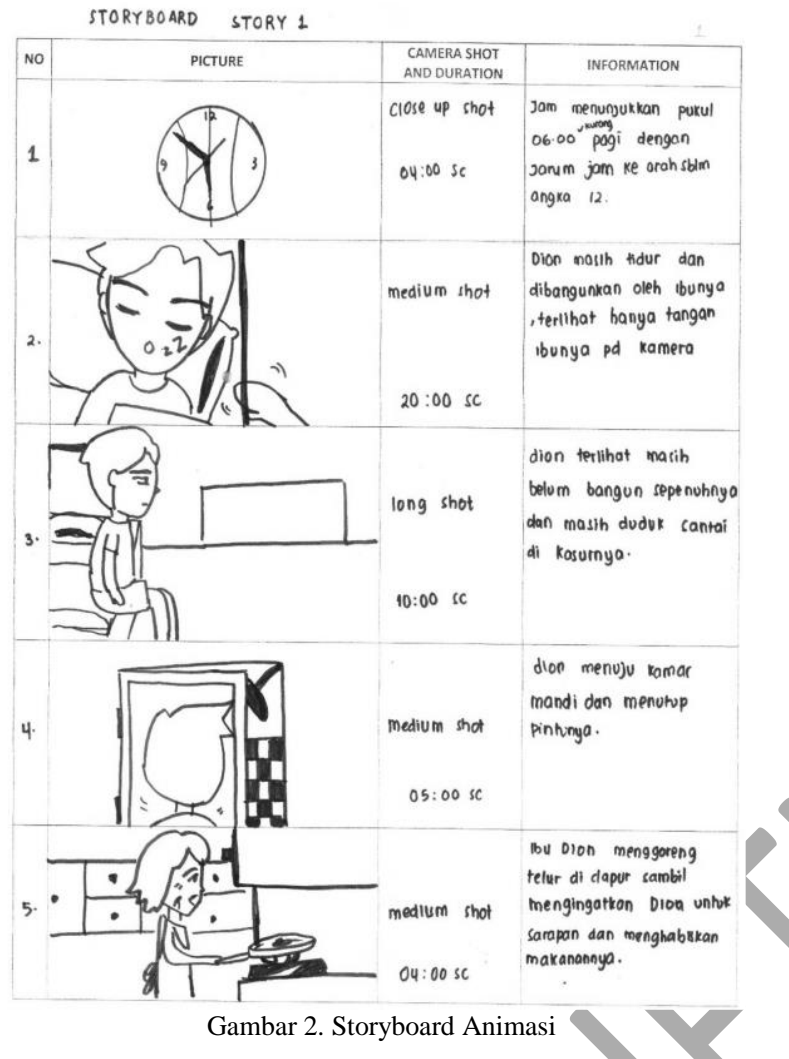

\section{Spesifikasi Alat}

Dalam proses pembuatan media pembelajaran interaktif "Speak Your Idiom" terdapat beberapa alat yang mendukung untuk membantu menyelesaikan proyek ini. Alat pendukung tersebut berupa perangkat keras (hardware) dan perangkat lunak (software).

a) Perangkat Keras (Hardware)

Perangkat keras yang digunakan penulis adalah sebuah Laptop dan Pen Tablet. Berikut adalah rincian dari penggunaan perangkat keras (hardware) yang digunakan dalam pembuatan media pembelajaran interaktif "Speak Your Idiom".

1) Laptop

Laptop yang digunakan untuk mengerjakan pembuatan user interface dan animating dalam skripsi. Laptop yang digunakan untuk mengerjakan pembuatan user interface yaitu ASUS A43E, sedangkan untuk mengerjakan animating yaitu Sony Vaio E Series 14P.

2) Pen Tablet

Pen Tablet yang yang digunakan yaitu Intuos Creative Pen Tablet merk Wacom dengan tipe CTL480. b) Perangkat Lunak (Software)

Perangkat lunak yang digunakan adalah Adobe Photoshop CS6, Adobe Illustrator CS6, Adobe After Effect CS6, Adobe Premiere Pro CS6.

\section{J. Realisasi Desain User Interface dan Animating}

Setelah perancangan media pembelajaran interaktif telah selesai, selanjutnya tahap realisasi akan dilaksanakan. Tahap realisasi merupakan tahap assembly pada metodologi Luther. Pada tahap ini mulai dibuat desain user interface dan animating.

1) Pembuatan Logo "Speak Your Idiom"

Dalam membuat suatu media pembelajaran interaktif umumnya memiliki logo judul media pembelajaran tersebut, pembuatan logo "Speak Your Idiom" ini, diawali dengan membuat storyboard/sketsa yang akan diaplikasikan pada media pembelajaran. Sketsa dari logo judul "Speak Your Idiom" yang akan dibuat bentuk digitalnya terlihat pada Gambar 3.



Gambar 3. Sketsa Logo Speak Your Idiom

Setelah membuat sketsa, dilakukan pembuatan bentuk visual digital dengan menggunakan perangkat lunak Adobe Photoshop. sketsa ini akan di-import ke dalam halaman artboard perangkat lunak Adobe Photoshop sebagai cetak biru (blueprint) atau acuan untuk membentuk bentuk digitalnya. Untuk membuat bentuk yang sesuai dengan gambar sketsa diperlukan tools yang terdapat dalam perangkat lunak ini. Penulis menggunakan horizontal type tool untuk membuat tulisan dan shape tool untuk membuat shape tambahan pada tulisan. Setelah itu gambar karakter yang telah disiapkan sebelumnya di-import dan tempatkan sesuai dengan cetak biru akan menghasilkan hasil akhir seperti Gambar 4.

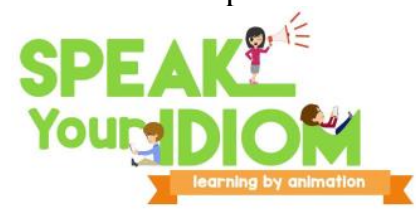

Gambar 4. Logo Speak Your Idiom

\section{2) Pembuatan Background User Interface}

Dalam membuat suatu desain user interface, diperlukan gambar yang menjadi background pada media pembelajaran interaktif tersebut. Pembuatan background ini diawali dengan pembuataan storyboard/sketsa objek yang ada pada background tersebut. Sketsa dari objek background yang akan dibuat bentuk digitalnya terlihat pada Gambar 5 . 


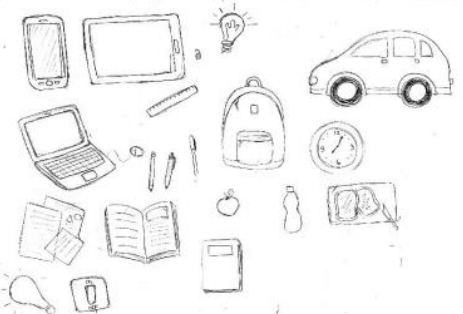

Gambar 5. Sketsa Objek untuk Background User Interface

Setelah membuat sketsa, dilakukan pembuatan bentuk visual digital background user interface dengan menggunakan perangkat lunak Adobe Illustrator. Sama seperti pembuatan logo sebelumnya, sketsa ini akan di-import ke dalam halaman artboard perangkat lunak Adobe Illustrator sebagai cetak biru (blueprint) atau acuan untuk membentuk bentuk digitalnya. Media pembelajaran interaktif "Speak Your Idiom" ini memiliki ukuran layar maksimal 1920x1080 pixels.

Untuk membuat bentuk yang sesuai dengan gambar, digunakan pen tablet. Tools yang digunakan pada saat penggunakan pen tablet yaitu paintbrush tool. Warna yang dibutuhkan disiapkan pada fill and stroke tool. Setelah semua objek dibuat, objek tersebut diduplikat dan diatur letaknya sehingga hasil akhir dari pembuatan background terlihat pada Gambar 6.

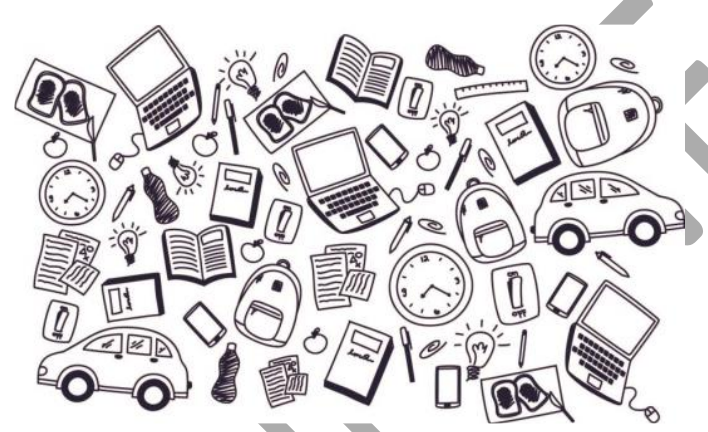

Gambar 6. Hasil Akhir Background

3) Pembuatan Desain User Interface

Pembuatan desain user interface berdasarkan sketsa yang telah dibuat sebelumnya. Sketsa kemudian diimport ke dalam Adobe Photoshop. Artboard yang penulis buat berukuran 1920x1080 pixels. Tahap selanjutnya, penulis membuat bentuk yang sesuai dengan cetak biru dengan menggunakan rectangle tool, ellipse tool, pen tool dan horizontal type tool sehingga didapat hasil user interface seperti pada Tabel 3 .
TABEL 3. HASIL USER INTERFACE

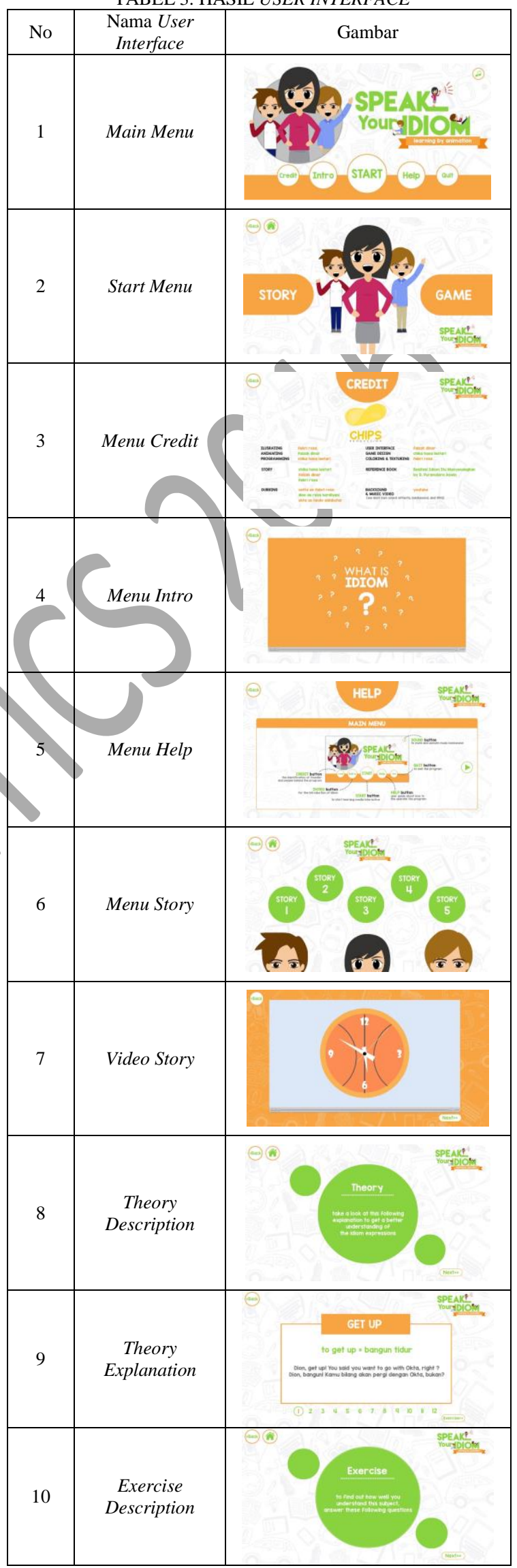




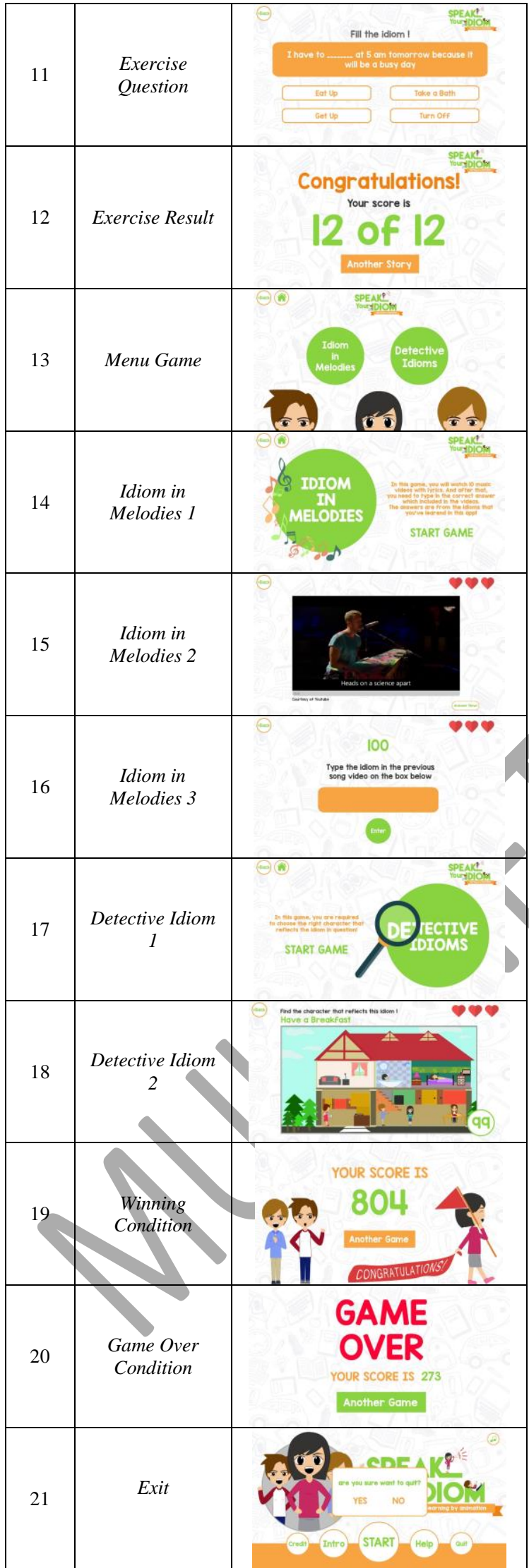

\section{Proses Animating Lips}

Dalam pembuatan sebuah cerita animasi diperlukan gerakan mulut pada karakter dalam animasi tersebut saat sedang berbicara. Animasi gerakan mulut dibuat dengan teknik replacement pada objek mulut yang dikerjakan dengan menggunakan perangkat lunak Adobe Premiere Pro. Proses animating lips ini, diawali dengan membuat artboard yang berukuran 500x500 pixels dan mengimport objek mulut dan audio rekaman suara karakter yang telah disiapkan sebelumnya. Adapun objek mulut yang digunakan terlihat pada Tabel 4 .

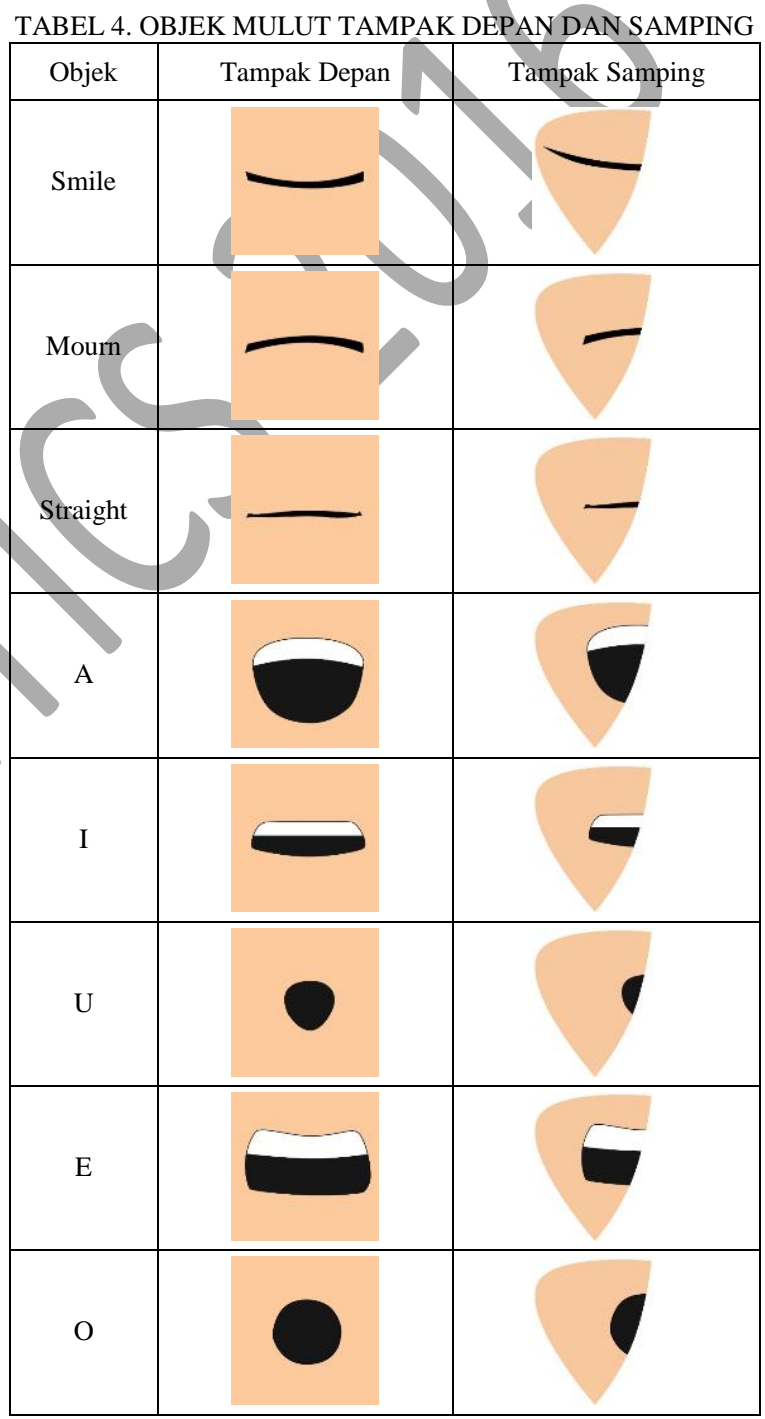

Audio rekaman suara karakter yang telah diimport dimasukan ke dalam timeline yang tersedia pada perangkat lunak Adobe Premiere Pro pada bagian audio. Sedangkan untuk bagian video dalam timeline diisi dengan objek mulut yang sesuai dengan yang terdengar dari audio rekaman suara karakter tersebut. 


\section{E. Proses Rigging Karakter}

Proses rigging karakter yaitu pemberian tulang (bone) pada objek untuk memudahkan dalam pembuatan animasi. Perangkat lunak yang digunakan dalam proses rigging ini yaitu Adobe After Effect dengan plug-in DUIK Tools. Objek karakter yang akan di-rigging memiliki format .psd, dimana di dalam .psd tersebut bagian-bagian badan dipisah (kepala, badan, pinggang, tangan, dan kaki). Objek tersebut kemudian di-import ke Adobe After Effect.

Untuk membuat bone diperlukan titik-titik puppet untuk penempatan letak bone tersebut. Pemberian titik ini menggunakan puppet pin tool yang disediakan oleh Adobe After Effect. Titik-titik puppet ini diletakkan pada bagian bagian yang diperlukan. Titik puppet merupakan lingkaran berwarna kuning yang terlihat pada Gambar 7 .



Gambar 7. Pemberian Titik Puppet

Setelah pemberian titik puppet selesai, penggunaan puppet starch tool dilakukan untuk membuat kaku objek. Selanjutnya titik - titik puppet ini akan dijadikan bones dengan bantuin plug-in DUIK. Bagian titik-titik puppet tersebut diseleksi lalu bagian bones pada DUIK dipilih. Kotak-kotak merah pada Gambar 8 merupakan bones yang telah dibuat. Bones ini harus di-parent-kan dengan layer yang bersangkutan agar dapat dianimasikan. Hal yang sama juga dilakukan pada objek-objek lain yang akan dianimasikan.

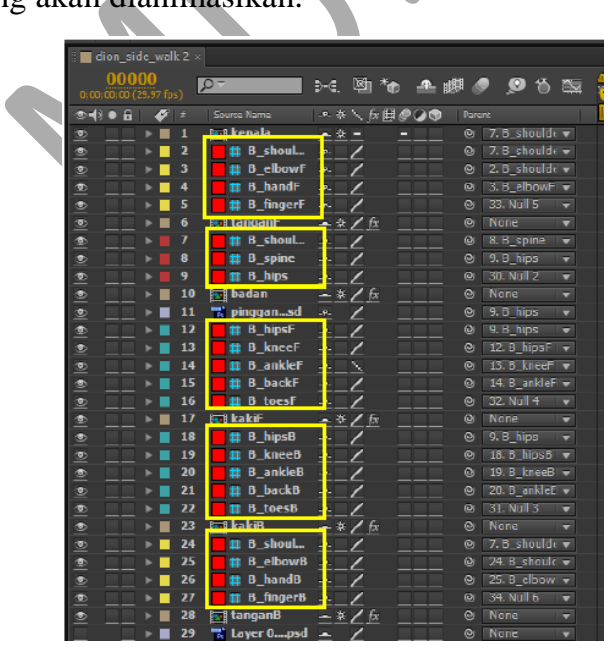

Gambar 8. Bones yang Telah Dibuat

\section{F. Proses Animating Karakter}

Tahapan selanjutnya yaitu proses animating karakter dengan menggunakan bones yang telah dibuat sebelumnya. Dalam menggerakkan karakter tersebut, dimanfaatkan keyframe dengan mengubah value rotate dan position yang ada pada properties layer tersebut. Keyframe ditandakan dengan bentuk seperti belah ketupat, dengan masing-masing keyframe menyimpan parameter setiap gerakan karakter. Animasi walk cycle yang terjadi yaitu seperti Gambar 9.

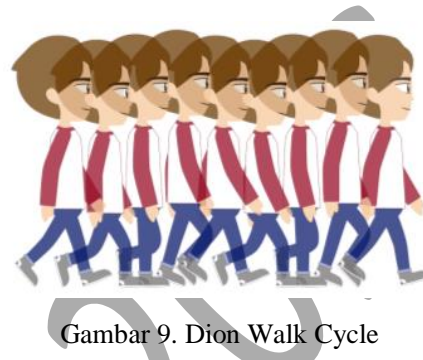

Hal ini dilakukan juga pada objek karakter sesuai dengan pergerakan yang dibutuhkan. Gambar 10 dan Gambar 11 merupakan hasil walk cycle dengan karakter yang berbeda dengan Gambar 9, sedangkan Gambar 12 merupakan runcycle dari karakter yang sama dengan Gambar 9.
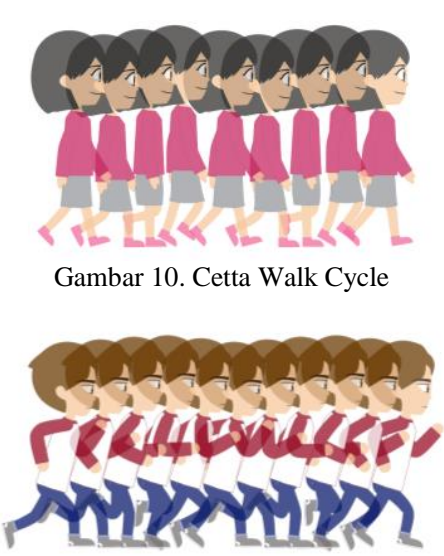

Gambar 11. Dion Run Cycle

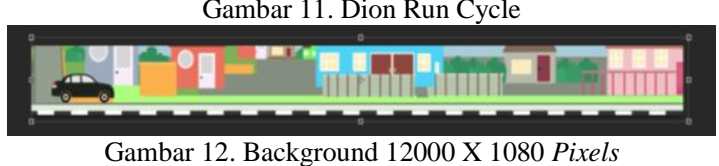

\section{G. Proses Animating Background}

Proses animating background hampir sama dengan animating karakter, hanya saja background tidak perlu di-rigging terlebih dahulu. Penulis membuat background bergerak dari arah kanan ke kiri. Artboard untuk animasi di Adobe After Effect berukuran 1920x1080 pixels, oleh karena itu background harus memiliki panjang yang lebih besar. Background yang digerakan memiliki ukuran 12000x1080 pixels seperti yang terlihat pada Gambar 13. 


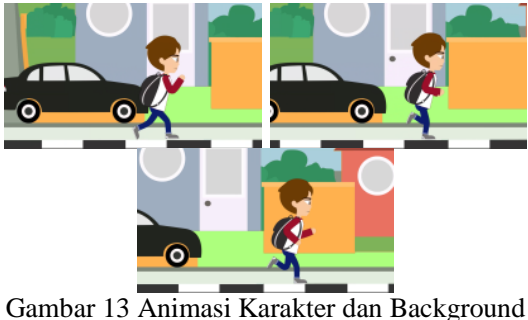

Background yang dibutuhkan tersebut di-import ke dalam Adobe After Effect. dan diletakkan pada composition yang memiliki artboard berukuran 1920x1080 pixels. Untuk menggerakkan background tersebut, dimanfaatkan properties position pada layer background. Keyframe dibuat dengan mengubah value pada properties position di bagian awal dan akhir sehingga akan membuat background bergerak dari kanan ke kiri. Selanjutnya yaitu menggabungkan animasi karakter dengan animasi background, sehingga akan terlihat seperti Gambar 14.

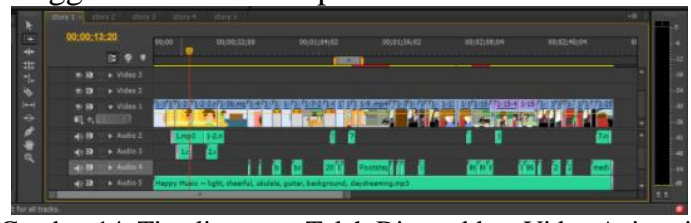

Gambar 14. Timeline yang Telah Dimasukkan Video Animasi, Sound Effect dan Backsound

Setelah semua proses animating selesai dilakukan render dengan menggunakan format $\mathrm{H} 264$ dan menghasilkan ekstensi .mp4.

\section{H. Compositing}

Setelah semua proses animating selesai dilakukan dan di-render di Adobe After Effect, maka tahap terakhir yaitu compositing. Penulis melakukan compositing di Adobe Premiere Pro, dengan mengimport semua video hasil render dari proses animating di Adobe After Effect. Selain video hasil render, juga di-import sound effect dan backsound yang dibutuhkan dan memasukkannya ke timeline.

Setelah itu penulis membuat subtitle dengan menggunakan title yang ada pada Adobe Premiere Pro. Dengan begitu maka tampilan workplace menjadi seperti Gambar 15.

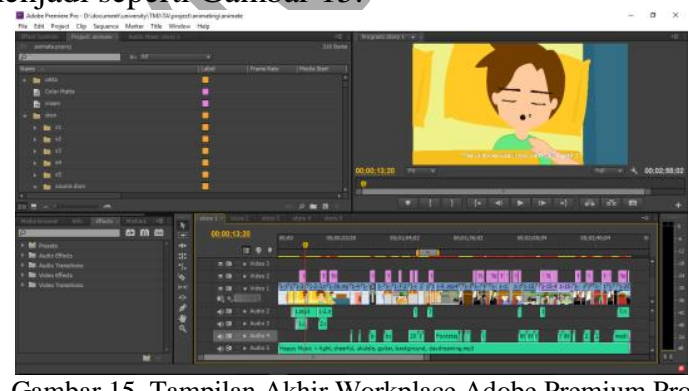

Gambar 15. Tampilan Akhir Workplace Adobe Premium Pro

Setelah semua selesai, hal terakhir yang dilakukan yaitu me-render dengan menggunakan format $\mathrm{H} 264$ yang menghasilkan ekstensi .mp4.

\section{PEMBAHASAN}

\section{A. Pengujian}

Pengujian media pembelajaran interaktif "Speak Your Idiom" dilakukan setelah proses pembuatan selesai. Tahap pengujian merupakan tahap testing pada metode Luther. Pengujian ini dilakukan terhadap hasil dari pembuatan user interface dan animating pada media pembelajaran interaktif.

\section{1) Deskripsi Pengujian}

Pengujian dibagi menjadi dua bagian, yaitu alpha testing dan beta testing. Alpha testing merupakan pengujian yang dilakukan oleh user pada lingkungan pengembang dan dilakukan untuk mengendalikan error system untuk segera dilakukan perbaikan. Setelah melakukan alpha testing, tahap pengujian selanjutnya yaitu beta testing. Beta testing adalah pengujian yang dilakukan oleh user pada lingkungan operasi user dengan keadaan aplikasi tidak dapat dikendalikan oleh pengembang. Setelah melakukan beta testing, user tersebut akan mengisi kuesioner yang telah disediakan. Pengujian beta testing dilakukan kepada 20 orang sebagai beta tester dari produk media pembelajaran interaktif ini.

2) Data Hasil Pengujian

Hasil dari alpha testing secara keseluruhan dapat dilihat pada Tabel 5, Tabel 6, dan Tabel 7.

TABEL 5. HASIL ALPHA TESTING PADA USER INTERFACE

\begin{tabular}{|c|c|c|c|}
\hline $\begin{array}{c}\text { Prinsip } \\
\text { Perancangan } \\
\text { User Interface }\end{array}$ & $\begin{array}{l}\text { Hasil yang } \\
\text { diharapkan }\end{array}$ & Hasil yang didapat & $\begin{array}{l}\text { Kesim } \\
\text { pulan }\end{array}$ \\
\hline $\begin{array}{l}\text { User } \\
\text { familiarity / } \\
\text { mudah } \\
\text { dikenali }\end{array}$ & $\begin{array}{l}\text { Penggunaan ikon } \\
\text { yang mudah } \\
\text { dikenal, seperti } \\
\text { penggunaan ikon } \\
\text { home untuk menuju } \\
\text { ke menu utama, } \\
\text { ikon back yang } \\
\text { biasa untuk menuju } \\
\text { halaman sebelum- } \\
\text { nya dan ikon tone } \\
\text { yang biasa untuk } \\
\text { audio. }\end{array}$ & $\begin{array}{l}\text { Ikon home yang } \\
\text { biasa digunakan } \\
\text { sebagai ikon untuk } \\
\text { menuju ke menu } \\
\text { utama, ikon back } \\
\text { yang biasa untuk } \\
\text { menuju halaman } \\
\text { sebelumnya dan } \\
\text { ikon tone yang } \\
\text { biasa untuk audio. }\end{array}$ & Valid \\
\hline $\begin{array}{l}\text { Consistency/ } \\
\text { "selalu } \\
\text { begitu" }\end{array}$ & $\begin{array}{l}\text { Konsisten dalam } \\
\text { bentuk dan } \\
\text { penem-patan } \\
\text { tombol, objek, } \\
\text { serta desain yang } \\
\text { konsisten pada } \\
\text { setiap scene. }\end{array}$ & $\begin{array}{l}\text { Penempatan } \\
\text { tombol back \& } \\
\text { home tetap. Desain } \\
\text { halaman dalam } \\
\text { menu Story dan } \\
\text { Game sama. } \\
\text { Desain halaman } \\
\text { pa-da saat cerita } \\
\text { anim-asi, Theory, } \\
\text { Exer-cise yang ada } \\
\text { pada setiap Story } \\
\text { sama. }\end{array}$ & Valid \\
\hline $\begin{array}{l}\text { Minimal } \\
\text { surprise/tidak } \\
\text { membuat } \\
\text { kaget } \text { user }\end{array}$ & $\begin{array}{l}\text { Fungsi tombol } \\
\text { sesuai dengan } \\
\text { desain tombol }\end{array}$ & $\begin{array}{l}\text { Fungsi setiap tom- } \\
\text { bol yg ada sesuai } \\
\text { de-ngan desain } \\
\text { tombol }\end{array}$ & Valid \\
\hline
\end{tabular}




\begin{tabular}{|c|c|c|c|}
\hline $\begin{array}{l}\text { User } \\
\text { Guidancel } \\
\text { bantuan }\end{array}$ & $\begin{array}{l}\text { Terdapat menu } \\
\text { help / bantuan } \\
\text { untuk user }\end{array}$ & $\begin{array}{l}\text { Terdapat menu } \\
\text { help / bantuan } \\
\text { untuk } \text { user }\end{array}$ & Valid \\
\hline $\begin{array}{l}\text { Recoverab- } \\
\text { ility / } \\
\text { Pemulihan }\end{array}$ & $\begin{array}{l}\text { Konfirmasi terha- } \\
\text { dap aksi yang me- } \\
\text { rusak seperti pada } \\
\text { saat } \text { user menekan } \\
\text { tombol Quit }\end{array}$ & $\begin{array}{l}\text { Konfirmasi pada } \\
\text { saat } \text { user menekan } \\
\text { tombol Quit }\end{array}$ & Valid \\
\hline $\begin{array}{l}\text { User } \\
\text { diversity / } \\
\text { keberagaman }\end{array}$ & $\begin{array}{l}\text { Tidak diterapkan, } \\
\text { karena produk yang } \\
\text { dibuat sudah } \\
\text { memiliki target } \\
\text { audiens yang jelas }\end{array}$ & $\begin{array}{l}\text { Tidak diterapkan, } \\
\text { karena produk yang } \\
\text { dibuat sudah } \\
\text { memiliki target } \\
\text { audiens yang jelas }\end{array}$ & Valid \\
\hline
\end{tabular}

TABEL 6. HASIL ALPHA TESTING PADA ANIMASI BERDASARKAN STORYBOARD

\begin{tabular}{|c|c|c|c|}
\hline Deskripsi & $\begin{array}{l}\text { Hasil yang } \\
\text { diharapkan }\end{array}$ & $\begin{array}{c}\text { Hasil yang } \\
\text { Didapat }\end{array}$ & $\begin{array}{c}\text { Kesim } \\
\text { pulan }\end{array}$ \\
\hline Story 1 & $\begin{array}{l}\text { Animasi yang } \\
\text { dihasilkan sesuai } \\
\text { dengan storyboard } \\
\text { Story } 1\end{array}$ & $\begin{array}{l}\text { Animasi yang } \\
\text { dihasilkan sesuai } \\
\text { dengan storyboar } \\
\text { Story } 1\end{array}$ & Valid \\
\hline Story 2 & $\begin{array}{l}\text { Animasi yang } \\
\text { dihasil-kan sesuai } \\
\text { dengan storyboard } \\
\text { Story } 2\end{array}$ & $\begin{array}{l}\text { Animasi yang } \\
\text { dihasilkan sesuai } \\
\text { dengan storyboar } \\
\text { Story } 2\end{array}$ & Valid \\
\hline Story 3 & $\begin{array}{l}\text { Animasi yang } \\
\text { dihasil-kan sesuai } \\
\text { dengan storyboard } \\
\text { Story } 3\end{array}$ & $\begin{array}{l}\text { Animasi yang } \\
\text { dihasilkan sesuai } \\
\text { dengan storyboard } \\
\text { Story } 3\end{array}$ & Valid \\
\hline Story 4 & $\begin{array}{l}\text { Animasi yang } \\
\text { dihasil-kan sesuai } \\
\text { dengan storyboard } \\
\text { Story } 4\end{array}$ & $\begin{array}{l}\text { Animasi yang } \\
\text { dihasilkan sesuai } \\
\text { dengan storyboar } \\
\text { Story } 4\end{array}$ & Valid \\
\hline Story 5 & $\begin{array}{l}\text { Animasi yang } \\
\text { dihasil-kan sesuai } \\
\text { dengan storyboard } \\
\text { Story } 5\end{array}$ & $\begin{array}{l}\text { Animasi yang } \\
\text { dihasilkan sesuai } \\
\text { dengan storyboar } \\
\text { Story } 5\end{array}$ & id \\
\hline
\end{tabular}

TABEL 7. HASIL ALPHA TESTING PADA ANIMASI BERDASARKAN 12 PRINSIP ANIMASI

\begin{tabular}{|c|c|c|c|c|}
\hline No & $\begin{array}{l}\text { Prinsip } \\
\text { Animasi }\end{array}$ & $\begin{array}{l}\text { Hasil yang } \\
\text { diharapkan }\end{array}$ & $\begin{array}{l}\text { Hasil yang } \\
\text { Didapat }\end{array}$ & $\begin{array}{l}\text { Kesim } \\
\text { pulan }\end{array}$ \\
\hline 1 & $\begin{array}{l}\text { Squash \& } \\
\text { Stretch }\end{array}$ & Tidak diterapkan & $\begin{array}{l}\text { Tidak } \\
\text { diterapkan }\end{array}$ & Valid \\
\hline 2 & $\begin{array}{l}\text { Anticipa- } \\
\text { tion }\end{array}$ & $\begin{array}{l}\text { Memberikan tanda } \\
\text { pada penonton me- } \\
\text { ngenai apa yang } \\
\text { akan dilakukan } \\
\text { oleh si karakter }\end{array}$ & $\begin{array}{l}\text { Gerakan } \\
\text { karakter saat } \\
\text { hendak ber-diri } \\
\text { dari posisi } \\
\text { duduk, berjalan, } \\
\text { \& berlari } \\
\end{array}$ & Valid \\
\hline 3 & & $\begin{array}{l}\text { Setiap detail } \\
\text { penampilan harus } \\
\text { tersampaikan } \\
\text { dengan sempurna } \\
\text { pada para } \\
\text { penonton }\end{array}$ & $\begin{array}{l}\text { Setiap gerakan, } \\
\text { ekspresi \& mood } \\
\text { dari karakter } \\
\text { yang ada dalam } \\
\text { cerita terlihat } \\
\text { jelas }\end{array}$ & Valid \\
\hline 4 & $\begin{array}{l}\text { Straight } \\
\text { Ahead and } \\
\text { Pose to } \\
\text { Pose }\end{array}$ & $\begin{array}{l}\text { Straight ahead, } \\
\text { menggambar secara } \\
\text { berurutan, dari } \\
\text { gam-bar pertama, } \\
\text { kedua, ketiga,\& } \\
\text { seterusnya. } \\
\text { Pose to pose, } \\
\text { pembuatan } \\
\text { animasi dengan } \\
\text { cara meng-gambar } \\
\text { hanya pada } \\
\text { keyframe-keyframe } \\
\text { tertentu saja }\end{array}$ & $\begin{array}{l}\text { Straight ahead } \\
\text { terdapat pada ani- } \\
\text { masi mulut yang } \\
\text { menyesuaikan } \\
\text { suara } \\
\text { Pose to pose } \\
\text { ter-dapat pada } \\
\text { semua gerakan } \\
\text { yang dilakukan } \\
\text { oleh karakter } \\
\text { dan } \\
\text { environment }\end{array}$ & Valid \\
\hline 5 & Follow & Follow through & Follow through & Valid \\
\hline
\end{tabular}

\begin{tabular}{|c|c|c|c|c|}
\hline & $\begin{array}{l}\text { Through } \\
\text { and } \\
\text { Overlapp- } \\
\text { ing Action }\end{array}$ & $\begin{array}{l}\text { tidak diterapkan } \\
\text { Overlapping } \\
\text { action, } \\
\text { serangkaian } \\
\text { gerakan yang } \\
\text { saling mendahului }\end{array}$ & $\begin{array}{l}\text { tidak diterapkan } \\
\text { Overlapping } \\
\text { action terdapat } \\
\text { pada per-gerakan } \\
\text { tangan \& kaki } \\
\text { ketika ber-jalan } \\
\text { dan berlari } \\
\end{array}$ & \\
\hline 6 & $\begin{array}{l}\text { Slow In \& } \\
\text { Slow Out }\end{array}$ & Tidak diterapkan & $\begin{array}{l}\text { Tidak } \\
\text { diterapkan }\end{array}$ & Valid \\
\hline 7 & Archs & $\begin{array}{l}\text { Membuat gerakan } \\
\text { animasi menjadi } \\
\text { lebih alami }\end{array}$ & $\begin{array}{l}\text { Sistem } \\
\text { pergerakan badan } \\
\text { pada karak-ter } \\
\text { yang mengikuti } \\
\text { pola }\end{array}$ & Valid \\
\hline 8 & $\begin{array}{l}\text { Secondary } \\
\text { Action }\end{array}$ & $\begin{array}{l}\text { Gerakan tambahan } \\
\text { untuk memperkuat } \\
\text { gerakan utama } \\
\text { supaya sebuah } \\
\text { animasi tampak } \\
\text { lebih realistik }\end{array}$ & $\begin{array}{l}\text { Gerakan tangan } \\
\text { pada saat karak- } \\
\text { ter berjalan/ber- } \\
\text { lari,gerakan } \\
\text { mata saat } \\
\text { anggota badan } \\
\text { bergerak }\end{array}$ & Valid \\
\hline 9 & Timing & $\begin{array}{l}\text { Berapa gambar yang } \\
\text { dibuat antara } 2 \\
\text { pose/in-beetween }\end{array}$ & $\begin{array}{l}\text { Lama objek } \\
\text { karak-ter maupun } \\
\text { objek } \\
\text { environment me- } \\
\text { lakukan suatu } \\
\text { per-gerakan } \\
\end{array}$ & Valid \\
\hline 10 & & $\begin{array}{l}\text { Membuat karakter } \\
\text { suatu animasi } \\
\text { menjadi menarik }\end{array}$ & $\begin{array}{l}\text { Visual karakter } \\
\text { pada cerita } \\
\text { animasi }\end{array}$ & Valid \\
\hline 1 & & $\begin{array}{l}\text { Upaya untuk men- } \\
\text { dramatisir sebuah } \\
\text { animasi dalam } \\
\text { ben-tuk rekayasa } \\
\text { gam-bar yang } \\
\text { bersifat hiperbolis }\end{array}$ & $\begin{array}{l}\text { Ekspresi marah } \\
\text { salah satu } \\
\text { karakter }\end{array}$ & Valid \\
\hline 12 & $\begin{array}{l}\text { Solid } \\
\text { Drawing }\end{array}$ & $\begin{array}{l}\text { Menggambar } \\
\text { karak-ter dalam } \\
\text { berbagai angle } \\
\text { sehingga ka-rakter } \\
\text { tersebut ter-lihat } \\
\text { bervolume dan } \\
\text { konsisten dalam se- } \\
\text { tiap frame animasi }\end{array}$ & $\begin{array}{l}\text { Karakter yang } \\
\text { me-miliki atribut } \\
\text { yang sama pada } \\
\text { bebera-pa angle, } \\
\text { yaitu tampak } \\
\text { depan, tampak } \\
\text { samping, dan } \\
\text { tampak } 3 / 4 \\
\end{array}$ & Valid \\
\hline
\end{tabular}

\section{B. Hasil Beta Testing}

Setelah melakukan beta testing, maka akan didapatkan data pengujian terhadap responden dari hasil pengujian seperti pada Tabel 8 dan Tabel 9.

TABEL 8. DISTRIBUSI RESPONDEN BERDASARKAN USIA

\begin{tabular}{cc}
\hline Usia & N \\
\hline $12-18$ & 9 \\
$19-24$ & 21 \\
\hline Total & 30 \\
\hline
\end{tabular}

TABEL 9. DISTRIBUSI RESPONDEN TERHADAP KUESIONER

\begin{tabular}{|c|c|c|c|c|c|c|}
\hline No & \multicolumn{5}{|c|}{ Pernyataan } \\
\hline 1 & $\begin{array}{r}\text { Pernyataan "Tampilan Visual Antarmuka Untuk Pengguna } \\
\text { (Warna dan Komposisi) Keseluruhan Menarik" }\end{array}$ \\
\hline \multirow{2}{*}{} & Jawaban & $\begin{array}{c}\text { Sangat } \\
\text { Setuju }\end{array}$ & Setuju & $\begin{array}{c}\text { Agak } \\
\text { Setuju }\end{array}$ & $\begin{array}{c}\text { Tidak } \\
\text { Setuju }\end{array}$ & $\begin{array}{c}\text { Sangat } \\
\text { Tidak } \\
\text { Setuju }\end{array}$ \\
\cline { 2 - 7 } & $\begin{array}{c}\text { Jumlah } \\
\text { Responden }\end{array}$ & 16 & 10 & 4 & 0 & 0 \\
\hline
\end{tabular}




\begin{tabular}{|c|c|c|c|c|c|c|}
\hline & Presentase & $\begin{array}{c}53,3 \\
\%\end{array}$ & $33,3 \%$ & $13,3 \%$ & $0 \%$ & $0 \%$ \\
\hline 2 & \multicolumn{6}{|c|}{$\begin{array}{l}\text { Pernyataan "Desain User interface / Antarmuka Pengguna } \\
\text { Sudah Efektif (Tidak Membingungkan)" }\end{array}$} \\
\hline & Jawaban & $\begin{array}{l}\text { Sangat } \\
\text { Setuju }\end{array}$ & Setuju & $\begin{array}{l}\text { Agak } \\
\text { Setuju }\end{array}$ & $\begin{array}{l}\text { Tidak } \\
\text { Setuju }\end{array}$ & $\begin{array}{l}\text { Sangat } \\
\text { Tidak } \\
\text { Setuju }\end{array}$ \\
\hline & $\begin{array}{c}\text { Jumlah } \\
\text { Responden }\end{array}$ & 10 & 18 & 2 & 0 & 0 \\
\hline & Presentase & $33,3 \%$ & $60 \%$ & $6,7 \%$ & $0 \%$ & $0 \%$ \\
\hline 3 & \multicolumn{6}{|c|}{ Pernyataan "Gerakan mulut dengan suara sudah selaras" } \\
\hline & Jawaban & $\begin{array}{l}\text { Sangat } \\
\text { Setuju }\end{array}$ & Setuju & $\begin{array}{l}\text { Agak } \\
\text { Setuju }\end{array}$ & $\begin{array}{l}\text { Tidak } \\
\text { Setuju }\end{array}$ & $\begin{array}{l}\text { Sangat } \\
\text { Tidak } \\
\text { Setuju }\end{array}$ \\
\hline & $\begin{array}{c}\text { Jumlah } \\
\text { Responden }\end{array}$ & 3 & 19 & 8 & 0 & 0 \\
\hline & Presentase & $10 \%$ & $63,3 \%$ & $26,7 \%$ & $0 \%$ & $0 \%$ \\
\hline 4 & \multicolumn{6}{|c|}{$\begin{array}{c}\text { Pernyataan "Gerakan karakter dan Background Pada } \\
\text { Animasi Sudah Sesuai" }\end{array}$} \\
\hline & Jawaban & $\begin{array}{l}\text { Sangat } \\
\text { Setuju }\end{array}$ & Setuju & $\begin{array}{l}\text { Agak } \\
\text { Setuju }\end{array}$ & $\begin{array}{l}\text { Tidak } \\
\text { Setuju }\end{array}$ & $\begin{array}{l}\text { Sangat } \\
\text { Tidak } \\
\text { Setuju }\end{array}$ \\
\hline & $\begin{array}{c}\text { Jumlah } \\
\text { Responden }\end{array}$ & 8 & 17 & 4 & 1 & 0 \\
\hline & Presentase & $26,7 \%$ & $56,7 \%$ & $13,3 \%$ & $3,33 \%$ & $0 \%$ \\
\hline 5 & \multicolumn{6}{|c|}{$\begin{array}{l}\text { Pernyataan "Kualitas Gambar Pada Video Animasi Sudah } \\
\text { Baik" }\end{array}$} \\
\hline & Jawaban & $\begin{array}{l}\text { Sangat } \\
\text { Setuju }\end{array}$ & Setuju & $\begin{array}{l}\text { Agak } \\
\text { Setuju }\end{array}$ & $\begin{array}{l}\text { Tidak } \\
\text { Setuju }\end{array}$ & $\begin{array}{l}\text { Sangat } \\
\text { Tidak } \\
\text { Setuju }\end{array}$ \\
\hline & $\begin{array}{l}\text { Jumlah } \\
\text { Responden }\end{array}$ & 10 & 19 & 1 & 0 & 0 \\
\hline & Presentase & $33,3 \%$ & $63,3 \%$ & $3,3 \%$ & $0 \%$ & $0 \%$ \\
\hline 6 & \multicolumn{6}{|c|}{$\begin{array}{c}\text { Pernyataan "Media Pembelajaran Interaktif "Speak Your } \\
\text { Idiom" Membantu Dalam Proses Pembelajaran Idiom } \\
\text { Bahasa Inggris" }\end{array}$} \\
\hline & Jawaban & $\begin{array}{l}\text { Sangat } \\
\text { Setuju }\end{array}$ & & $\begin{array}{l}\text { Agak } \\
\text { Setuju }\end{array}$ & $\begin{array}{l}\text { Tidak } \\
\text { Setuju }\end{array}$ & $\begin{array}{l}\text { Sangat } \\
\text { Tidak } \\
\text { Setuju }\end{array}$ \\
\hline & $\begin{array}{c}\text { Jumlah } \\
\text { Responden }\end{array}$ & 14 & 16 & & 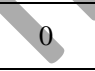 & 0 \\
\hline & Presentase & $46,7 \%$ & $53,3 \%$ & $0 \%$ & $0 \%$ & $0 \%$ \\
\hline 7 & \multicolumn{6}{|c|}{$\begin{array}{l}\text { Pernyataan "Media Pembelajaran Interaktif "Speak Your } \\
\text { Idiom" Layak Dipublikasikan Secara Luas" }\end{array}$} \\
\hline & Jawaban & at & Setuju & $\begin{array}{l}\text { Agak } \\
\text { Setuju }\end{array}$ & $\begin{array}{l}\text { Tidak } \\
\text { Setuju }\end{array}$ & $\begin{array}{l}\text { Sangat } \\
\text { Tidak } \\
\text { Setuju }\end{array}$ \\
\hline & $\begin{array}{c}\text { Jumlah } \\
\text { Responden }\end{array}$ & & 13 & 6 & 0 & 0 \\
\hline & Presentase & $36,7 \%$ & $43,3 \%$ & $20 \%$ & $0 \%$ & $0 \%$ \\
\hline 8 & \multicolumn{6}{|c|}{$\begin{array}{l}\text { Pernyataan "Konten Multimedia (Teks, Gambar, Audio, } \\
\text { Video, Animasi) Dalam Media Pembelajaran Interaktif } \\
\text { "Speak Your Idiom" Lengkap" }\end{array}$} \\
\hline & Jawaban & $\begin{array}{l}\text { Sangat } \\
\text { Setuju }\end{array}$ & Setuju & $\begin{array}{c}\text { Agak } \\
\text { Setuju }\end{array}$ & $\begin{array}{l}\text { Tidak } \\
\text { Setuju }\end{array}$ & $\begin{array}{l}\text { Sangat } \\
\text { Tidak } \\
\text { Setuju }\end{array}$ \\
\hline & $\begin{array}{c}\text { Jumlah } \\
\text { Responden }\end{array}$ & 12 & 15 & 3 & 0 & 0 \\
\hline & Presentase & $40 \%$ & $50 \%$ & $10 \%$ & $0 \%$ & $0 \%$ \\
\hline
\end{tabular}

\section{PENUTUP}

Berdasarkan hasil penelitian "Pembuatan User Interface dan Animating pada Media Pembelajaran
Interaktif Idiom Bahasa Inggris" dapat disimpulkan bahwa:

1) Penelitian ini berhasil membuat user interface dan animating pada media pembelajaran interaktif.

2) Proses pembuatan desain user interface pada media pembelajaran interaktif "Speak Your Idiom" dilakukan bertahap mulai dengan menentukan konsep, membuat sketsa, dan kemudian realisasi pembuatan desain user interface menggunakan perangkat lunak Adobe Photoshop CS6 dan Adobe Illustrator CS6. User interface yang dibuat terdiri dari 21 layout user interface, yaitu layout main menu, start menu, menu credit, menu intro, menu help, menu story, video story, theory description, theory explanation, exercise description, exercise question, exercise result, menu game, idiom in melodies 1 , idiom in melodies 2 , idiom in melodies 3, detective idiom 1 , detective idiom 2, winning condition, game over condition, dan exit.

3) Proses animating pada media pembelajaran interaktif "Speak Your Idiom" dilakukan bertahap mulai dengan menentukan konsep, membuat skenario, membuat storyboard, dan kemudian realisasi proses animating menggunakan perangkat lunak Adobe After Effect CS6 dengan bantuan plug-in DUIK Tools dan perangkat lunak Adobe Premiere Pro CS6. Hasil video animasi ini memiliki format .mp4. Story 1 memiliki durasi 2 menit 38 detik dengan kapasitas ukuran sebesar $33,4 \mathrm{Mb}$, story 2 memiliki durasi 2 menit 9 detik dengan kapasitas ukuran sebesar 22,7 $\mathrm{Mb}$, story 3 memiliki durasi 1 menit 22 detik dengan kapasitas ukuran sebesar $45,9 \mathrm{Mb}$, story 4 memiliki durasi 2 menit 8 detik dengan kapasitas ukuran sebesar 24,4 Mb, dan story 5 memiliki durasi 1 menit 17 detik dengan kapasitas ukuran sebesar 43,1 Mb.

4) Berdasarkan hasil alpha testing, pembuatan user interface menerapkan 5 dari 6 prinsip perancangan user interface dan proses animating menerapkan 10 dari 12 prinsip animasi.

5) Berdasarkan hasil beta testing, user menyukai tampilan user interface dan tidak merasa kebingungan pada saat menjalankan media pembelajaran interaktif "Speak Your Idiom". Hal ini dibuktikan dengan adanya presentase sebesar 86,693,3\% pada gabungan jawaban "sangat setuju" dan "setuju" di kategori user interface.

6) Berdasarkan hasil beta testing, user merasa animasi sudah sesuai dengan jalan cerita. Hal ini dibuktikan dengan adanya presentase sebesar 73,3$83,4 \%$ pada gabungan jawaban "sangat setuju" dan "setuju" di kategori animasi. Sedangkan untuk kualitas video mendapatkan presentase sebesar 96,6\% yang membuktikan bahwa kualitas video pada animasi sudah baik.

7) Berdasarkan hasil beta testing, pengguna menilai bahwa media pembelajaran interaktif "Speak Your Idiom"membantu dalam mempelajari idiom dan layak untuk dipublikasikan, pengguna juga menilai 
bahwa konten multimedia yang terdapat pada media pembelajaran sudah lengkap. Hal ini dibuktikan dengan adanya presentase sebesar $80-100 \%$ pada gabungan jawaban "sangat setuju" dan "setuju" di kategori media pembelajaran interaktif.

\section{Saran}

1) Desain user interface pada media pembelajaran interaktif dapat dibuat semenarik dan seefektif mungkin sehingga para user mudah dalam mengoperasikannya.

2) Pembuatan user interface akan lebih baik lagi jika dapat menerapkan seluruh pinsip perancangan user interface.

3) Proses animating dilakukan dengan lebih detail, baik pada karakter maupun pada environment.

4) Pembuatan animasi akan lebih halus dan lebih hidup dengan menerapkan 12 prinsip animasi.

\section{REFERENSI}

[1] Binanto, I. (2010). Multimedia Digital - Dasar Teori dan Pengembangannya. Yogyakarta: Andi.

[2] Ananto, B. S. (2011). Implementasi Sistem Bantuan Penderita Buta Warna: Desain Antarmuka Pengguna, Sistem Tes Buta Warna dengan Ishihara, dan Transformasi Warna Pada Sistem Realitas Tertambah. Depok: Universitas Indonesia.

[3] Nari, J., Rindengan, Y., Tulenan, V., Sentinuwo, S, \& Lantang, O. (2014). Perancangan Studio Musik Bambu Dengan Perspektif Animasi 3D. E-journal Teknik Informatika, 4 (2), 1-7.

[4] Ramayulis, P. D. (2015). Dasar - Dasar Kependidikan (Suatu Pengantar Ilmu Kependidikan) (1st ed.). Jakarta: Kalam Mulia.

[5] Hendriani, M. (2010). Media Pembelajaran tentang Pola Makan Seimbang Bagi Anak-Anak Usia 4-6 Tahun Melalui Permainan. Jurusan Desain Komunikasi Visual Nirmana , $12(1), 36-44$.
[6] Siswanto, J. (2011). Compact Disk Online (CD-O) Sebagai Multimedia Interaktif Pembelajaran Fisika Berbasis Proyek. Jurnal Penelitian Pembelajaran Fisika , 2 (1), 56-70.

[7] Khurriyatur, R. (2013). Perancangan Interaktif Company Profile PT. Simpati Global Surabaya. STIKOM Surabaya.

[8] Yuniarto, A., Suwachid, \& Estriyanto, Y. (2013). Pengembangan Media Pembelajaran Pada Mata Kuliah Praktik CAD I (AUTO CAD 2 Dimensi) Di Program Studi Pendidikan Teknik Mesin Jurusan Pendidikan Teknik Dan Kejuruan Fakultas Keguruan Dan Ilmu Pendidikan Universitas Sebelas Maret. Jurnal Nosel, 1 (4).

[9] Sullivan, J. J., \& Podo, H. (2011). Kamus Ungkapan Inggris-Indonesia (Dictionary of Idioms and Idiomatic Expression) (3rd ed.). Jakarta: Gramedia Pustaka Utama.

[10] Ardhiyani, J., \& Bachtiar, A. M. (2014). Analisis User Interface Media Pembelajaran Pengenalan Kosakata Untuk Anak Tunarungu. Makassar: Konferensi Nasional Sistem Informasi (KNSI)

[11] Suteja, B. R., \& Harjoko, A. (2008). User Interface Design for e-Learning System. Seminar Nasional Aplikasi Teknologi Informasi

[12] Athari, M. A. (2015). Modeling Karakter dan Lighting pada Film Animasi 3D "Jujur Itu Lebih Baik" dalam Upaya Membangkitkan Jiwa Kejujuran Anak. Depok: Politeknik Negeri Jakarta

[13] Purnomo, W., \& Andreas, W. (2013). Teknik Animasi 2 Dimensi. Malang: Kementerian Pendidikan \& Kebudayaan.

[14] Effendhy, A. (2015). Otodidak Photoshop CC Dari Basic Hingga Mahir. Huta Paint.

[15] Botello, C. (2013). Adobe Illustrator CS6 Revealed. New York: Cengage Learning.

[16] Dufresne, N. (2015). Rigging Duik Animation: User Guide Version 15. Duduf.

[17] Sugianto, M. (2012). Seri Belajar Cepat: Adobe Premiere Pro CS5. Yogyakarta: Andi.

[18] Saputra, W., \& Purnama, B. E. (2012). Pengembangan Multimedia Pembelajaran Interaktif Untuk Mata Kuliah Organisasi Komputer. Sentra Penelitian Engineering dan Edukasi , 4 (2), 60-67.

[19] Wijayanto, R. (2014). Perancangan Animasi Interaktif Pembelajaran Bahasa Inggris Untuk Kelas 2 pada MI Nurul Falah Ciater. Evolusi, II (1), 1-11.

[20] Aswin, B. P. (2015). Resitasi Idiom Itu Menyenangkan. Jakarta: Gramedia Widiasarana Indonesia. 